\title{
Den rettslige bevisbyrden
}

\author{
Markus Jerk $\varnothing$, postdoktor
}

Markus Jerk (født 1980) er cand.jur. (2007) og ph.d. (2015), begge fra Universitetet i Oslo. Han er postdoktor ved Institutt for privatrett, Det juridiske fakultet, UiO, hvor han underviser i blant annet rettslig metode og Examen facultatum, og forsker på ymse problemstillinger i skjæringspunktet mellom juss og filosofi. Han er forfatter av Bevisvurderingens rettslige rammer Bevistema, bevisbyrde, beviskrav, Oslo 2017.

Artikkelen presenterer byggesteinene i bevisvurderingens rettslige rammer. Den redegjør for det rettslige bevistemaet og beviskravet, for sondringen mellom den rettslige og den argumentative bevisbyrden samt bevisføringsbyrden, og hvordan sistnevnte påvirkes av evidens samt faktiske og legale presumsjoner. Mytene om blant annet bevisbyrderegler samt delt og omvendt bevisbyrde oppklares underveis.

\section{Innledning}

Få begreper står mer sentralt i jussen. Få har vært mer myteomspunnet eller innhyllet i like mye uklarhet. Ordet «bevisbyrde» brukes med den største naturlighet av jurister, som et ord i deres eget stammespråk, men hvem som har bevisbyrden, hva bevisbyrden er, og hva vi i det hele tatt $b \phi r$ mene med ordet «bevisbyrde», har vært gjenstand for nær endeløse diskusjoner i rettsvitenskapen.

I første halvdel av det 20. århundre var bevisbyrden også gjenstand for omfattende debatt i norsk teori, med Torstein Eckhoffs Tvilsrisikoen fra 1943 som den siste i en rekke av monografier om temaet. ${ }^{1}$ Som han skriver, var oppfatningene sterkt delte og antallet divergerende teorier nesten like stort som antallet forfattere som har befattet seg med emnet. ${ }^{2}$

Etter dette stilnet debatten. For moderne norske lesere er bevisbyrdens problem derfor kanskje ikke så godt kjent. Men vi trenger ikke se lenger enn over landegrensen for tegn på den respekt det har blitt møtt med. Per Henrik Lindblom har kalt det et av prosessrettens tre «fete» problemer, ${ }^{3}$ og Per Olof Bolding er særlig ærbødig i sin omtale av det når han skriver at det er utenkelig at noen skulle kunne få «siste ord» om dette emnet, eller endog presentere et tilforlatelig bilde av noe som skulle gjøre seg fortjent til betegnelsen «gjeldende rett». ${ }^{4}$

Et sentralt spørsmål i diskusjonene, som har vært diskutert helt tilbake til romerretten, er om det er mulig å oppstille generelle kriterier om hvem som har bevisbyrden. Dette har etter hvert, slik Bolding antyder, blitt ansett som et uløselig problem. Til enhver tenkelig generalisering vil det tilsynelatende gjelde en rekke konkrete unntak, hvor bevisbyrden ligger på den annen part - såkalt omvendt bevisbyrde - eller hvor begge parter har bevisbyrden for sine respektive forhold - såkalt delt bevisbyrde.

\footnotetext{
${ }^{1}$ Se nærmere om tidligere forskning og fremveksten av vårt system med bevisbyrde og beviskrav i Markus Jerk $\varnothing$, Bevisvurderingens rettslige rammer - Bevistema, bevisbyrde, beviskrav, Oslo 2017, s. 89-101 og 107-112.

${ }^{2}$ Torstein Eckhoff, Tvilsrisikoen: (bevisbyrden), Oslo 1943, s. 1.

${ }^{3}$ Per Henrik Lindblom, «Kommentarer om lagkommentarer», i Sena uppsatser, Stockholm 2006, s. $77-$ 105 , på s. 90.

${ }^{4}$ Per Olof Bolding, Bevisbörda och beviskrav, Skrifter utgivna av Juridiska Föreningen i Lund, nr. 61, 1983, s. 7.
} 
I boken Bevisvurderingens rettslige rammer - Bevistema, bevisbyrde, beviskrav har jeg argumentert for at dette synet er misforstått. Årsaken til at bevisbyrden i mange tilfeller anses å være delt eller omvendt, er at forskjellige anvendelser av ordet «bevisbyrde» blandes sammen. Ordet «bevisbyrde» brukes i forskjellige relasjoner og betydninger, og løsningen på problemet ligger $\mathrm{i}$ atskillelsen av disse. Med en bedre forståelse av de forskjellige elementene som inngår i bevisvurderingens rettslige rammer, går dette «uløselige» problemet i oppløsning. Med denne artikkelen ønsker jeg å formidle en slik forståelse til en bredere krets av lesere. For ikke å gjenta meg unødig viser jeg til boken for et utdypende forsvar og flere eksempler.

Etter at den teoretiske utforskningen av bevisbyrden stagnerte, har dette en gang så pregnante emnet blitt forvist til prosessfagenes periferi, hvor det behandles kort og ikke alltid like konsist. Dette mener jeg er uheldig. Ikke bare fordi disse korte behandlingene av problemstillingen har sine mangler, men også fordi rammene for bevisvurderingen har nær tilknytning til rettsanvendelsen som sådan. Forståelsen av emnet hører etter mitt syn til den juridiske allmenndannelsen. Denne artikkelen er derfor skrevet med helt ferske studenter for øye; jeg har forsøkt ikke å forutsette noen forkunnskaper hos leseren. Men forhåpentlig vil også erfarne jurister kunne ha utbytte av artikkelen.

Det er ikke mulig å få en god forståelse av bevisbyrden uten en forståelse av hva man har bevisbyrden for. Vi må derfor begynne med forståelsen av et rettslig bevistema (punkt 2). Deretter ser vi nærmere på beviskravet (punkt 3) og den rettslige bevisbyrden, som er risikoen for at beviskravet ikke er oppfylt (punkt 4). En annen form for bevisbyrde er bevisføringsbyrden, som behandles i punkt 5. Her skal vi også se hvordan denne kan veksle mellom partene som en følge av evidens, faktiske presumsjoner og legalpresumsjoner. Den argumentative bevisbyrden, som er relatert til andre forhold enn det rettslige bevistemaet, omtales kort i punkt 6 , før noen oppsummerende ord i punkt 7 .

\section{Det rettslige bevistemaet}

I juridisk teori og praksis brukes termen «bevistema» på forskjellige måter, men gjerne i en vid og uforpliktende forstand. Johs. Andenæs omtaler bevistemaet som det som «er gjenstand for bevis». ${ }^{5}$ Jo Hov bruker uttrykket om «det som skal bevises», og føyer til at «[d]et en ønsker å føre bevis for, er et eller annet som har rettslig betydning». ${ }^{6}$ I en slik vid forstand finnes det knapt grenser for hva som kan utgjøre et bevistema. Et bevistema er simpelthen ett eller annet - stort eller smått, sentralt eller marginalt - som noen søker å bevise. ${ }^{7}$

Denne artikkelens emne forutsetter en snevrere og mer presist definert forståelse av hva et rettslig bevistema er. Det er nemlig ikke mulig å få en god forståelse av bevisbyrden uten en forståelse av hva man har bevisbyrden for. Vi må derfor begynne med å stille et annet spørsmål: Hva er det som skal bevises? Med dette spørsmålet sikter jeg til hva som utgjør nødvendige og tilstrekkelige betingelser for en rettsvirkning. Prosessuelle bestemmelser går jeg ikke inn på.

Spørsmålet er dessverre lite synlig i jusstudiet. I en praktikumsoppgave er faktum alltid gitt, slik at kun tolkning og subsumsjon gjenstår. I praksis, derimot, er faktum sjelden gitt, og det vil ofte være et større samspill mellom jussen og det faktuelle. Ikke bare er det slik - i et rettsanvendelsesperspektiv - at rettsreglene forteller oss de rettslige virkningene av et gitt faktum. Det er også slik - i et bevisvurderingsperspektiv - at rettsreglene, med sine rettsvilkår, angir hvilke handlinger med videre som

\footnotetext{
${ }^{5}$ Johs. Andenæs, Norsk straffeprosess, 4. utgave ved Tor-Geir Myhrer, Oslo 2009, s. 160.

${ }^{6}$ Jo Hov, Rettergang II, Oslo 2010, s. 1065.

${ }^{7}$ Men bruken av termen er som sagt varierende; enkelte forfattere bruker ordet $\mathrm{i}$ en snevrere forstand, ikke ulik den forståelse av «rettslig bevistema» som jeg legger til grunn her, sml. f.eks. Inge Lorange Backer, Norsk sivilprosess, Oslo 2015, s. 279; Eckhoff, Tvilsrisikoen, s. 92 flg.; Eivind Kolflaath, Språk og argumentasjon - med eksempler fra juss, Bergen 2004, s. 128; Anne Robberstad, Sivilprosess, 4. utgave, Bergen 2018, s. 272; Jens Edvin A. Skoghøy, Tvisteløsning, 3. utgave, Oslo 2017, s. 940 flg.
} 
vil kunne få forskjellige rettslige virkninger, og dermed også hvilke rettslige krav som kan bringes inn for retten, og hva det er nødvendig og tilstrekkelig å føre adekvate bevis for, for at en bestemt rettsvirkning skal inntre.

Eksempel 1 (drap): En fredag ettermiddag blir Lars Holm funnet død i sin leilighet i Oslo, med en $\emptyset \mathrm{ks}$ plantet i hodeskallen. Under etterforskningen finner politiet fingeravtrykkene til Peder Ås på økseskaftet. Påtalemyndigheten trekker den konklusjon at han må ha forårsaket Holms død, og tar ut tiltale. Hva er det som i et slikt tilfelle skal bevises?

Svaret følger av straffeloven ${ }^{8} \S 275$, som passer godt til dette scenariet: «Den som dreper en annen, straffes med fengsel fra 8 inntil 21 år». Hva er det som må bevises for å dømme Ås etter denne bestemmelsen? Jo, det er naturlig nok at Peder Ås har drept Lars Holm. Dette vil være et eksempel på det jeg, i den snevrere forståelse av bevistemaet som jeg vil frem til, vil kalle et rettslig bevistema.

En rettsregel som strl. $\S 275$ knytter rettslige følger til faktuelle vilkår. Disse kan skrives på formen hvis-så, der hvis-leddet uttrykker bestemmelsens rettsvilkår, og så-leddet uttrykker bestemmelsens rettsfølge, eller rettsvirkning. Hvis bestemmelsens rettsvilkår er oppfylt, så skal rettsfølgen inntre. Skriver vi strl. § 275 på en slik form, får vi: «Hvis en person har drept en annen, så straffes personen med fengsel fra 8 inntil 21 år.» Kombinerer vi dette med det rettslige bevistemaet, lar det oss oppstille følgende logisk gyldige argument, som er et eksempel på rettsanvendelsessyllogismen:

Rettslig premiss $\quad$ Hvis en person har drept en annen, så straffes personen med fengsel fra 8 inntil 21 år.

Faktisk premiss $\quad$ Peder Ås har drept Lars Holm.

Konklusjon Peder Ås straffes med fengsel fra 8 inntil 21 år.

Som vi kan se av rettsanvendelsessyllogismen, er det rettslige bevistemaet en nødvendig og tilstrekkelig betingelse for rettsvirkningen etter bestemmelsen i dette konkrete tilfellet, forutsatt at ingen unntaksbestemmelser kommer til anvendelse. ${ }^{9}$ (Den konkrete straffen må fastsettes ut fra retningslinjer for straffutmåling, som følger av rettspraksis og forarbeider med videre.)

Rettsreglene er generelle normer: de knytter følger til generelle vilkår. I en rettslig tvist oppstår spørsmålet om vilkåret er oppfylt i et konkret tilfelle. Rettsvilkåret er altså generelt, mens det som skal bevises - det rettslige bevistemaet - er konkret. Det rettslige bevistemaet fremkommer ved en konkretisering av rettsvilkåret. Mens et rettsvilkår enten er oppfylt eller ikke oppfylt, er et bevistema enten sant eller usant; rettsvilkåret er oppfylt hvis og bare hvis det rettslige bevistemaet er sant.

Legg merke til at mens det er nødvendig at rettsregelens rettsvilkår er oppfylt, for at rettsvirkningen skal inntre, er det uvesentlig hvordan det er oppfylt. Strl. § 275 krever ikke at drapet ble begått spesifikt med $\varnothing \mathrm{ks}$ - eller med et annet drapsvåpen, for den saks skyld. Og bestemmelsen krever heller ikke at drapet ble begått på et bestemt tidspunkt, eller med et bestemt motiv, og så videre. Ved fastleggingen av det rettslige bevistemaet må vi derfor se bort fra slike videre konkretiseringer av rettsvilkåret, som sier at dette er oppfylt på en bestemt måte. Det rettslige bevistemaet er utelukkende en minimal konkretisering av rettsvilkåret (i en regel som knytter rettslige følger til faktuelle vilkår). Det går ut på at rettsvilkåret er oppfylt i et konkret tilfelle, men utbroderer ikke hvordan - på en måte som ville innebære å innfortolke ytterligere betingelser i rettsvilkåret. ${ }^{10}$

I dette eksempelet er det allikevel klart, så fremt $\varnothing$ ksen var drapsvåpenet, at påtalemyndigheten må godtgjøre at Peder Ås drepte Holm med et hugg med øksen. Og for å bevise dette er det igjen nødvendig å

\footnotetext{
${ }^{8}$ Lov 20. mai 2005 nr. 28 om straff (strl.).

${ }^{9}$ Eksempelet er noe forenklet, ved at kravet om forsett, jf. strl. § 21, og andre straffbarhetsbetingelser er underforstått (men vi kan også innfortolke kravet om forsett i uttrykket «drept en annen», og tilsvarende for andre straffbarhetsbetingelser).

${ }^{10}$ Se nærmere i Jerk $\varnothing$ (2017) s. 47-57 og 72-87.
} 
godtgjøre at Ås var i Holms leilighet på drapstidspunktet. For å styrke sin argumentasjon kan det også hende at påtalemyndigheten vil argumentere for at drapet skyldtes en krangel mellom Holm og Ås, eller at Ås tok livet av Holm for å unnslippe gjeld etter en narkotikahandel. Og dersom obduksjonen av Holm viser at han døde momentant av et hugg med øksen en gang i tidsrommet 21-24, natt til fredag, og overvåkningskameraer på Oslo S viser at Ås, som innrømmer å ha besøkt Holm tidligere på kvelden, kl. 21.00 gikk om bord på toget i retning Drammen, hvor han bor, vil påtalemyndigheten kanskje også ende opp med å føre bevis for at Ås gikk av toget på Nationaltheatret stasjon, ikledd et nytt antrekk og løsbart, for så å ta seg tilbake til Holms leilighet, hvor han begikk drapet. Alt dette, og mere til, kan det være nødvendig å føre bevis for, for at Ås skal bli dømt for drapet på Holm. Men alle disse andre, mer konkrete forholdene som det føres bevis for, vil utelukkende være midler til å bevise at Peder Ås har drept Lars Holm; det er ikke disse forholdene loven krever bevis for. I enhver sak kan det være en rekke forskjellige, andre bevistemaer. Om man ønsker å forstå bevisbyrden - og å oppnå en klar forståelse av argumentasjon om bevisspørsmål - er det helt avgjørende at disse ikke blandes sammen med sakens rettslige bevistema.

Eksempel 2 (mangel/retting): I februar 2018 kjøpte Marte Kirkerud en smartklokke hos Lillevik elektro. Klokken kostet kr. 1799, og i sin markedsføring oppga butikken at klokken var «vannavvisende» og «perfekt for den aktive mosjonist». Hun ble svært skuffet da klokken etter en svømmetur samme sommer sluttet å fungere, men etter at en kamerat påpekte at «vannavvisende» ikke er det samme som «vanntett», slo hun seg til ro med at feilen var hennes egen, og la det hele til side. Det var først etter at hun hadde kommet i gang med studiet i rettsvitenskap samme høst, at hun begynte å lure på om hun kanskje hadde en sak likevel. Hun tok med seg klokken til butikken da hun i høstferien var tilbake i Lillevik, men ble blankt avvist. Salgsrepresentanten hun snakket med, konstaterte at klokken ikke lenger fungerte, men hevdet at dette ikke var butikkens ansvar. Han påpekte at klokken kun var oppgitt å være «vannavvisende». Marte kunne heller ikke bevise at det var noe galt med klokken da hun kjøpte den, og hun måtte ha bevisbyrden i et tilfelle som dette. Dessuten måtte en jusstudent forstå at retten til å reklamere for lengst var gått tapt. Frustrert over denne responsen vurderte Marte om hun skulle gå til sak. Hun mente at hun i det minste burde ha krav på å få reparert klokken. Men hun var usikker på løsningen av de rettslige spørsmålene saken reiste, og hva var det egentlig hun måtte bevise om hun skulle få medhold?

Den som reklamerer på en vare vil - heldigvis - sjelden bli avkrevd ytterligere bevis eller bli møtt med argumenter om hvem som har bevisbyrden. Og for ordens skyld: Et slikt argument gir også mindre mening i en slik situasjon. Riktignok kan vi snakke om en form for bevisbyrde på mange forskjellige arenaer - en argumentativ bevisbyrde ${ }^{11}$ - men i jussen gir det hovedsakelig mening å snakke om bevisbyrden innenfor rammene av en rettslig prosess. Tar man med seg en ødelagt vare til en butikk, er man i en annen situasjon, hvor det i utgangspunktet er opp til partene selv om de vil komme til enighet uten at den ene eller den andre har bevisbyrden. Heldigvis har de fleste butikker også bedre rutiner for håndtering av reklamasjoner enn Lillevik elektro, og de vil normalt være innstilt på å finne frem til mer smidige løsninger i tilfeller hvor kunden kan tenkes å ha rett. Det er derfor sjelden en liten sak som denne må bringes inn for domstolene, og vi må ta stilling til spørsmål om bevis. Men eksempelet er godt egnet til å belyse noen flere sider ved hva det er som skal bevises, så la oss forutsette at Marte vurderer å gå til sak for å kreve at klokken blir reparert. Hva er det hun da må bevise?

Som i det forrige eksempelet følger svaret av rettsreglene - i dette tilfellet av forbrukerkjøpsloven ${ }^{12} \S$ 26 første ledd bokstav b), jf. § 29, som (lett omskrevet) slår fast at hvis en vare har en mangel som ikke skyldes forhold på forbrukerens side, kan forbrukeren kreve mangelen rettet. Et rettslig bevistema som, ved en minimal konkretisering, følger av dette, er at Martes smartklokke har en mangel som ikke skyldes forhold på hennes side. Dette lar oss stille opp følgende rettsanvendelsessyllogisme:

\footnotetext{
${ }^{11}$ Se nærmere i punkt 6.

${ }^{12}$ Lov 21. juni $2002 \mathrm{nr} .34$ om forbrukerkjøp (fkjl.).
} 
Rettslig premiss

Faktisk premiss

Konklusjon
Hvis en vare har en mangel som ikke skyldes forhold på forbrukerens side, kan forbrukeren kreve mangelen rettet.

Martes smartklokke har en mangel som ikke skyldes forhold på hennes side.

Marte kan kreve å få mangelen rettet.

Marte skal altså få medhold om hun kan føre adekvate bevis for at smartklokken har en mangel som ikke skyldes forhold på hennes side. På tilsvarende vis som i det forrige eksempelet oppstiller ikke bestemmelsen et krav om en spesifikk form for mangel. Rettsvilkåret vil være oppfylt så fremt klokken har en mangel, uten hensyn til hva mangelen mer konkret måtte gå ut på. Også i dette tilfellet vil det imidlertid være slik at hun ikke kan godtgjøre at den har en mangel, uten å legge frem bevis for at dette på en mer konkret måte er tilfellet, men det er altså ikke dette loven krever bevis for.

Formuleringen «å drepe en annen» har en nokså klar betydning i dagligspråket, som loven drar veksler på. Om vi med våre egne øyne hadde sett Peder Ås slå Lars Holm i hjel med en øks, ville det vært uproblematisk å konstatere at Ås hadde drept Holm. Ås ville neppe vinne gehør om han innvendte at dét var et tolkningsspørsmål. For ordet «mangel» forholder det seg annerledes. Vi kan med våre egne øyne konstatere at en klokke er ødelagt, men det er ikke dermed sagt at den har en mangel. Ordet har en særegen rettslig betydning, som må utpensles gjennom en rettslig tolkning før man kan fastslå om en mangel foreligger.

Betydningen er nærmere fastlagt i fkjl. $§ 16$ jf. $\S 15$. Disse er i sin helhet, sammen med rettspraksis med videre, relevante for forståelsen av ordets betydning, og dermed for hvordan vi kan trekke opp yttergrensene for hva som kan utgjøre en mangel. For enkelhets skyld nøyer jeg meg allikevel her med å gjengi noen momenter. En ting har blant annet en mangel dersom den ikke samsvarer med det som følger av avtalen ( $\$ 15$ første ledd), eller om den ikke samsvarer med de egenskaper forbrukeren har grunn til å forvente ved kjøp av en slik ting ( $\$ 15$ andre ledd bokstav b), eller med opplysninger som selgeren har gitt om tingen eller dens bruk ( $\$ 16$ første ledd bokstav c).

På bakgrunn av disse momentene, og andre som fremkommer ved tolkningen, vil vi kunne oppstille en mer presis forståelse - ikke bare av rettsvilkåret, men også av det rettslige bevistemaet. En mer presis forståelse av hva ordet «mangel» betyr, gir oss en mer presis forståelse av hva det innebærer, eller kan innebære, at Martes smartklokke har en mangel. Dette gir oss en presisering av det rettslige bevistemaet. ${ }^{13}$ En slik presisering forandrer ikke hva det er som skal bevises. - Det vil fortsatt være dekkende å si at det som skal bevises, er at klokken har en mangel; presiseringen gir oss bare en mer presis forståelse av hva dette innebærer. Om enkelte av lovens angivelser av hva som kan utgjøre en mangel, slik som kravene til varens innpakning i fkjl. § 15 annet ledd bokstav e, ikke er relevante, kan vi se bort fra disse delene. Det vil innebære en spesifisering av det rettslige bevistemaet. ${ }^{14}$

Av momentene som fremkommer gjennom presiseringen, vil det blant annet kunne være relevant for Martes sak at varen har en mangel dersom den ikke samsvarer med opplysninger som selgeren har gitt om tingen eller dens bruk. Hvilke opplysninger selgeren har gitt, som for eksempel at klokken er «vannavvisende», er noe som kan være gjenstand for bevis. Dette er et faktisk spørsmål. Hva «vannavvisende» betyr, er derimot ikke et rent faktisk spørsmål. Dette beror på en tolkning av uttrykket (og dermed, indirekte, på en tolkning av språklige normer). Ut fra en alminnelig forståelse av uttrykket er det kanskje ikke klart hvor vannavvisende noe må være for å kunne kalles «vannavvisende». Men det kan være at dette ordet brukes i en mer presis betydning i markedet for salg av smartklokker og lignende produkter. Og dette er også noe som det kan føres bevis for. Det kan være at ordet kun blir brukt om produkter som tåler regnvær, men ikke bruk i vann. Eller så kan det tenkes at ordet (ellers) blir brukt om produkter som kan brukes til svømming (i kontrast til «vannavstøtende» produkter som kanskje kun tåler

\footnotetext{
${ }^{13}$ Se nærmere om presiseringer i Jerk $\varnothing$ (2017) s. 68-72.

${ }^{14}$ Se nærmere om spesifiseringer i Jerk $\varnothing$ (2017) s. 66-68.
} 
regnvær), men ikke til dykking under en viss dybde. En faktisk undersøkelse kan derfor gi oss opplysninger som er relevante ved tolkningen av uttrykket «vannavvisende», samt ved vurderingen av hva en forbruker har grunn til å forvente ved kjøp av en klokke som markedsføres som vannavvisende.

Det er to ting det særlig er verdt å merke seg her. Det første er hvordan det er en vekselvirkning mellom det rettslige og det faktuelle. ${ }^{15}$ Hva ordet «mangel» betyr, er i utgangspunktet et rettslig spørsmål, og loven gir flere holdepunkter ved tolkningen av dette uttrykket. Ved den nærmere vurderingen av hva det kan innebære at klokken har en mangel, trekkes det inn faktuelle forhold, blant annet hvilke opplysninger selger har gitt. Dette reiser igjen nye tolkningsspørsmål (om forståelsen av språklige normer): Hvordan skal vi forstå ordet «vannavvisende»? Dette kan lede videre til nye faktiske spørsmål, om hvordan dette ordet har blitt brukt i dette markedet. Og dette vil igjen ha betydning for den endelige tolkningen, eller, kanskje mer presist, for subsumsjonen: Det har betydning for hvilke faktiske forhold som kan subsumeres under rettsvilkåret.

Det andre er hvordan dette samspillet - fordi det påvirker vår forståelse av hva som kan utgjøre en mangel ved smartklokken - i neste omgang blir avgjørende for hva det er som eventuelt videre må bevises. Hvis en vannavvisende klokke kun tåler å brukes i regnvær, men ikke til svømming, synes det som om Marte har en dårlig sak, og den vil ikke styrkes av at hun fører bevis for at klokken ble ødelagt under en svømmetur. Hvis en vannavvisende klokke derimot skal tåle svømming, men ikke dykking på mer enn 5 meters dyp, forholder saken seg annerledes. Da blir det relevant å føre bevis for at skaden oppstod under en svømmetur. Tolkningen vil altså ha betydning for hva det må føres adekvate bevis for, for at en part skal få medhold. Og i tolkningen/subsumsjonen kan også forskjellige faktiske opplysninger få en slik betydning.

Disse forholdene er også noe man bør være seg bevisst om man vurderer å bringe en sak inn for domstolene. Moralen er: En rasjonell rettslig aktør vil aldri på måfå føre bevis for et tilfeldig faktisk forhold, for så å sette sin lit til at et slikt faktisk forhold vil få et lykksalig rettslig utfall. Hun vil i stedet søke å tilpasse det hun fører bevis for, til en forståelse av rettsreglene, og om nødvendig argumentere for en tolkning av rettsreglene som er tilpasset det hun er i stand til å bevise.

Hva om Marte går til sak og blir møtt med den innsigelse at hun har reklamert for sent - hva er det som da skal bevises? På samme måte som over følger det som skal bevises, av loven. Fkjl. § 27 første ledd jf. fjerde ledd slår fast (lett omskrevet) at hvis forbrukeren ikke reklamerer innen rimelig tid etter at han eller hun oppdaget eller burde ha oppdaget mangelen, taper forbrukeren retten til å gjøre mangelen gjeldende. Dette lar oss oppstille et annet rettslig bevistema: at Marte ikke har reklamert innen rimelig tid etter at hun oppdaget eller burde ha oppdaget mangelen. Også her vil det nærmere innholdet i blant annet «rimelig tid» måtte bero på en tolkning, som vil resultere i en presisering av dette rettslige bevistemaet. Jeg går ikke nærmere inn på dette bevistemaet, men bringer det opp som en illustrasjon på at det i en og samme sak kan være flere rettslige bevistemaer. Slike sideordnede bevistemaer må gjøres til gjenstand for atskilte vurderinger. ${ }^{16}$

Fordi et rettslig bevistema er en (minimal) konkretisering av rettsvilkåret i en regel som knytter rettslige følger til faktuelle vilkår, følger det at to bevistemaer vil være forskjellige enten om de er avledet av forskjellige rettsregler, eller om de er forskjellige konkretiseringer av rettsvilkåret i samme regel.

Innvendingen om for sen reklamasjon er et eksempel på det førstnevnte. Andre eksempler kan være at det innvendes at et krav er innfridd eller foreldet, eller at det påberopes at en tiltalt var utilregnelig på handlingstidspunktet eller handlet i nødverge. Et eksempel på det andre kan være at begge parter, på forskjellige grunnlag, krever erstatning av den andre part. Men det kan også være at partene påberoper seg den samme regel i tilknytning til det samme saksforholdet. For eksempel kan det være at partene i et avtaleforhold er uenige om hva de faktisk har avtalt om beregningen av honorarets størrelse. Det kan også være at partene har vidt forskjellige forståelser av avtalens realytelse: Knoll og Tott er begge av den oppfatning at de har inngått en muntlig avtale, slik at begge bygger sine krav på de samme rettslige vilkårene om avtaleinngåelse, men mens Knoll hevder at han og Tott har inngått avtale om kjøp av en

${ }^{15}$ Se nærmere Markus Jerkø, «Det faktuelles rolle i rettsanvendelsen», Lov og Rett, 2014, s. 445-464.

${ }^{16}$ Om sideordnede bevistemaer, se Jerk $\varnothing$ (2017) s. 57-62. 
hatt, er Tott skråsikker på at avtalen gjelder en katt. I det usannsynlige tilfellet at denne saken skulle kommet for retten, ville vi stått overfor to forskjellige konkretiseringer av vilkårene for en avtaleinngåelse, og dermed to sideordnede bevistemaer, som det måtte foretas atskilte vurderinger av.

\section{Beviskravet}

Det følger av rettsreglenes hvis-så-karakter at hvis rettsvilkåret er oppfylt, så skal rettsvirkningen inntre. Og fordi det rettslige bevistemaet er en (minimal) konkretisering av rettsvilkåret, så skal rettsvirkningen inntre hvis det rettslige bevistemaet er sant. Over ble dette illustrert med blant annet følgende syllogisme:

Rettslig premiss

Faktisk premiss

Konklusjon
Hvis en person har drept en annen, så straffes personen med fengsel fra 8 inntil 21 år.

Peder Ås har drept Lars Holm.

Peder Ås straffes med fengsel fra 8 inntil 21 år.

Det rettslige premisset i syllogismen synes å implisere et krav om at det rettslige bevistemaet må være sant for at rettsvirkningen skal inntre. En dommer vil imidlertid, for så vidt det rettslige bevistemaet er gjenstand for en bevisvurdering, aldri kunne oppnå helt sikker kunnskap om hvorvidt det er sant eller ikke. Dommeren var ikke til stede da drapet fant sted, men må på bakgrunn av sakens beviser gjøre seg opp en mening om hvor troverdig det rettslige bevistemaet er.

Vårt rettssystem bygger på prinsippet om fri bevisvurdering. Dette innebærer at retten hverken er bundet av partenes argumentasjon om bevisspørsmål eller av rettslige normer som bestemmer hva som kan sluttes fra det enkelte bevis, eller hvor stor vekt det enkelte bevis har. Bevisbedømmeren er heller ikke bundet til en bestemt metode eller fremgangsmåte, men står fritt til å gi sin mest grundige og reflekterte vurdering av hva hun kan slutte fra sakens beviser. ${ }^{17}$

Et slikt system forutsetter også et mål - et beviskrav - som angir hvor sikker dommeren må være, eller hvor gode grunner hun må ha, for å legge til grunn at det rettslige bevistemaet er sant. Mens det rettslige bevistemaet utgjør en hypotese som bevisbedømmeren skal ta stilling til, angir beviskravet det minstekrav til bevis som må være oppfylt for at denne hypotesen skal legges til grunn i dommen som bevist.

I straffesaker er hovedregelen at (all) rimelig tvil skal komme den tiltalte til gode; det må være bevist utover enhver rimelig tvil at tiltalte er skyldig etter tiltalen. I vårt eksempel medfører dette at påtalemyndigheten må bevise utover enhver rimelig tvil at Peder Ås har drept Lars Holm; dersom det hersker rimelig tvil om dette, skal Peder Ås frifinnes.

Om vi implementerer beviskravet i syllogismen over, kan vi se hvordan beviskravet modifiserer den materielle rettsregelens rettsvilkår, og dermed også hva det er som må bevises for at Peder Ås skal kunne straffes for drapet på Lars Holm:

Rettslig premiss

Hvis det er bevist utover enhver rimelig tvil at en person har drept en annen, så straffes personen med fengsel fra 8 inntil 21 år.

Faktisk premiss Det er bevist utover enhver rimelig tvil at Peder Ås har drept Lars Holm.

Konklusjon Peder Ås straffes med fengsel fra 8 inntil 21 år.

Sammenhengen mellom rettsregelens rettsvilkår og beviskravet støtter opp under forståelsen av det rettslige bevistemaet som en minimal konkretisering av rettsvilkåret. Det avgjørende er utelukkende om

${ }^{17}$ Se nærmere om prinsippet i Jerkø (2017) s. 409 flg. 
det kan bevises utover enhver rimelig tvil at Ås har drept Holm; tvil for eksempel om hvorvidt han gjorde det før eller etter kl. 21.00, skal være uten betydning. Som også Høyesterett har uttalt, er det bare rimelig tvil «om de deler av faktum som har direkte betydning for vurderingen av tiltaltes skyld, ... som kan lede til at beviskravet ikke anses oppfylt. At det i en straffesak kan være tvil om enkelte deler av det faktiske hendelsesforløp som ikke har direkte betydning for avgjørelsen av skyldspørsmålet, vil være en helt normal situasjon.» 18

I våre dager ser vi på strafferettens beviskrav som en viktig rettssikkerhetsgaranti som skal beskytte tiltalte mot uriktige domfellelser. Det sies gjerne, med William Blackstones ord, at det er bedre at ti skyldige går fri, enn at én uskyldig straffes. ${ }^{19}$ Kravet forutsetter en overbevisning som er betydelig sterkere enn sannsynlighetsovervekt. På den annen side er det konsensus om at en rent teoretisk mulighet for at bevistemaet er usant, ikke er tilstrekkelig for frifinnelse. Men hva som mer presist ligger i beviskravet, er uklart. ${ }^{20}$ Det har røtter i eldgammel kristen moralteologi, og dets opprinnelige mening har langt på vei gått tapt $\mathrm{i}$ historien. ${ }^{21} \mathrm{I}$ vår tid finnes det ikke noe opplagt korrekt svar på hvordan vi bør forstå uttrykket «rimelig tvil». ${ }^{22}$

I sivile saker er hovedregelen et krav om alminnelig sannsynlighetsovervekt. ${ }^{23}$ Regelen innebærer at det rettslige bevistemaet skal legges til grunn som bevist hvis og bare hvis retten finner det mer sannsynlig at det er sant, enn at det er usant. I eksempelet om retting må Marte derfor godtgjøre at det er mer sannsynlig at smartklokken har en mangel som ikke skyldes forhold på hennes side, enn at den ikke har det.

Ordet «sannsynlighet» kan gis ulike tolkninger, men i rettslige bevisvurderinger gir det normalt mest mening å snakke om subjektive sannsynligheter, som simpelthen er en persons grad av overbevisning. ${ }^{24}$ Dommeren(e) må føle seg mer overbevist, på bakgrunn av sakens beviser, om at klokken har en mangel som ikke skyldes forhold på Martes side, enn at den ikke har det.

Torstein Eckhoff hadde argumentert for dette såkalte overvektsprinsippet allerede i Tvilsrisikoen fra 1943, men hans oppfatning festet seg ikke i praksis umiddelbart; de følgende tiårs praksis tyder på at det i mange saker ble krevd noe mer enn simpel sannsynlighetsovervekt. Det var først med Rt. 1992 s. 64 Ppilledom II, som i teorien gjerne fremheves som et veiskille, ${ }^{25}$ at prinsippet ble sementert som hovedregelen i sivile saker. Eckhoffs begrunnelse var at man ved å legge til grunn det mest sannsynlige over tid vil oppnå et størst antall korrekte avgjørelser. ${ }^{26}$ Dette mener jeg er en fornuftig begrunnelse, som også har nytt nær unison tilslutning frem til i dag. ${ }^{27}$

${ }^{18}$ Rt. 2004 s. 1063 (avsnitt 9).

${ }^{19}$ Se nærmere i bl.a. Vidar Halvorsen, «Hvorfor er det bedre at ti skyldige går fri enn at en uskyldig blir dømt?», Tidsskrift for strafferett, 2002, s. 234-243; Alexander Volokh, «n Guilty Men», University of Pennsylvania Law Review 146, nr. 1 1997, s. 173-216.

${ }^{20}$ Se ellers nærmere i Hov (2010) s. 1161-1168; Jerkø (2017) s. 245-252; Asbjørn Strandbakken, Uskyldspresumsjonen: "In dubio pro reo», Bergen 2003, s. 339-372.

${ }^{21}$ Om beviskravets historiske røtter, se James Q Whitman, The Origins of Reasonable Doubt: Theological Roots of the Criminal Trial, New Haven 2008; Jerkø (2017) s. 247-252.

${ }^{22} \mathrm{Om}$ noen fors $\varnothing \mathrm{k}$ på å presisere beviskravet, se Eivind Kolflaath, «Bevist utover enhver rimelig tvil», Tidsskrift for Rettsvitenskap, 2011, s. 135-196. Om empirisk forskning på praktiseringen av det, se Jerkø (2017) s. 286-294.

${ }^{23}$ Se nærmere Hov (2010) s. 1153-1155; Jerkø (2017) s. 242-245; Robberstad (2018) s. 300-301.

${ }^{24}$ Se Jerkø (2017) s. 65-66 og 273-279 passim. En god og lettfattelig, generell introduksjon til elementær sannsynlighetsteori er Ian Hacking, An Introduction to Probability and Inductive Logic, Cambridge 2001.

${ }^{25}$ Se Hov (2010) s. 1155; Skoghøy (2017) s. 914-915. Se også Jerkø (2017) s. 243-245.

${ }^{26}$ Eckhoff, Tvilsrisikoen, s. 64.

${ }^{27}$ Det kritiske unntaket er Magne Strandberg, Beviskrav i sivile saker, Bergen 2012, s. 461-494. Han kaller Eckhoffs påstand et postulat, og argumenterer for at det av flere grunner ikke er holdbart. Jeg har svart på denne kritikken i Jerkø (2017) s. 297-312. 
Noen ganger er lovens ordlyd bestemmende for beviskravet. Etter kjøpsloven ${ }^{28} \S 62$ (1) første punktum kan en part heve kjøpet allerede før tiden for oppfyllelse dersom det på tidspunktet er «klart» at det vil inntre kontraktbrudd som vil gi parten hevingsrett. Etter voldsoffererstatningsloven ${ }^{29} \S 3$ siste ledd tilkjennes slik erstatning kun når det foreligger «klar sannsynlighetsovervekt». Og etter arvelova ${ }^{30} \S 57$ annet ledd faller en testamentarisk disposisjon bort når dokumentet er ødelagt eller overstrøket så det er «truleg» at den ikke skal gjelde, eller når det på grunn av senere inntrådte omstendigheter er «tvillaust» at den ikke skal gjelde. Hvordan disse uttrykkene skal forstås, og hvordan de eventuelt avviker fra hovedregelen i sivile saker, må avgjøres ved en alminnelig rettslig tolkning.

I andre tilfeller kan holdepunkter i rettspraksis, forarbeider, lovshistorien eller reelle hensyn gi grunnlag for å oppstille et beviskrav som avviker fra en av hovedreglene. I Rt. 1979 s. 143 la Høyesterett til grunn at vurderingen av om tiltalte var tilregnelig på handlingstidspunktet, skal foretas etter et svakere beviskrav enn det alminnelige i straffesaker. ${ }^{31}$ Rt. 1999 s. 14, som gjaldt administrativ inndragning av fisk fanget i strid med dagjeldende saltvannsfiskelov ${ }^{32}$, gir en god illustrasjon på bredden i de momenter som kan være relevante ved fastsettelsen av beviskravet. Her fant et flertall på tre dommere at hovedregelen $\mathrm{i}$ sivile saker måtte fravikes til fordel for et krav om klar sannsynlighetsovervekt, mens et mindretall på to dommere mente at strafferettens beviskrav måtte gjelde. ${ }^{33}$

Gjennom rettspraksis har Høyesterett også signalisert at det må gjelde et unntak fra hovedregelen i enkelte typer sivile saker. Det viktigste eksempelet er at beviskravet skjerpes (alternativt senkes) i saker hvor konsekvensene av uriktig dom anses å være verre i den ene retning enn i den andre. Dette vil blant annet være tilfellet når det er spørsmål om en part er skyldig i et straffbart eller et annet sterkt klanderverdig forhold. Rt. 1996 s. 864 gjaldt et krav om oppreisning for seksuelle overgrep mot et barn under 14 år. Her ble oppfatningen karakterisert som et «alminnelig prinsipp», som ifølge retten

«må lede til at det stilles strengere krav til beviset for de handlinger som danner grunnlag for et slikt oppreisningskrav enn vanlig sannsynlighetsovervekt. På den annen side kan det ikke stilles så strenge krav som for å konstatere straffeskyld. I en sak av denne karakter mener jeg at det må kreves en klar sannsynlighetsovervekt for å legge til grunn at det påståtte overgrep er begått.» ${ }^{34}$

Hva som menes med «klar» sannsynlighetsovervekt, er ikke klart, men for $\emptyset$ vrig er dette et fornuftig unntak som harmonerer godt med beviskravets funksjon og rasjonelle begrunnelse. ${ }^{35} \mathrm{En}$ sak om oppreisning for et straffbart forhold, som for eksempel overgrep, dreier seg ikke bare om en mulig pengeoverføring mellom to personer. Den saksøkte, eller tiltalte i straffesaken, risikerer også å bli merket som en overgriper, og det kan få dyptgripende personlige konsekvenser for vedkommende, i form av blant annet sosial fordømmelse, utstøtelse fra lokalsamfunnet og reduserte muligheter i arbeidsmarkedet. Såfremt vi ser på disse potensielle, personlige omkostningene som større for saks økte enn for saks øker, vil en uriktig dom mot saksøkte være en mer alvorlig feil for rettsvesenet enn en uriktig dom i favør saksøkte. Derfor bør retten også være sikrere i sin vurdering for å idømme erstatning i en slik sak, enn i en sak om et alminnelig økonomisk tap. Det tilsier et strengere beviskrav. Hvis man også er av den oppfatning at det er en mindre alvorlig feil å idømme en uskyldig overgrepstiltalt et oppreisningsansvar,

${ }^{28}$ Lov 13. mai 1988 nr. 27 om kjøp (kjl.).

${ }^{29}$ Lov 20. april $2001 \mathrm{nr} .13$ om erstatning fra staten for personskade voldt ved straffbar handling m.m.

${ }^{30}$ Lov 3. mars 1972 nr. 5 om arv m.m.

${ }^{31}$ Se nærmere Markus Jerk $\varnothing$, «Beviskravet for tilregnelighet», Lov og Rett, 2015, s. 558-560.

${ }^{32}$ Lov 3. juni $1983 \mathrm{nr}$. 40 om saltvannsfiske m.v.

${ }^{33}$ Se også Hov (2010) s. 1152-1153; Jerk (2017) s. 252-256; Skoghøy (2017) s. 926-933.

${ }^{34}$ Rt. 1996 s. 864, på s. 869-870. Se også Hov (2010) s. 1155-1157; Jerkø (2017) s. 256-260; Robberstad (2018) s. 301-303; Skoghøy (2017) s. 933-936.

${ }^{35}$ Se nærmere om beviskravets funksjon og begrunnelse i Jerkø (2017) s. 313-330; Jerkø (2015) s. 563573. 
enn det er å dømme personen til fengselsstraff, bør beviskravet i saker som dette legges et sted mellom sannsynlighetsovervekt og bevis utover enhver rimelig tvil.

I rettspraksis har det også blitt lagt til grunn at beviskravet, om enn i beskjeden grad, kan senkes eller skjerpes i disfavør av en part som ikke har bidratt til å sikre bevis i en situasjon hvor han eller hun alene hadde mulighet og oppfordring til det. Et eksempel er Rt. 1990 s. 688, en forsikringssak hvor beviskravet ble justert i disfavør av en bilist som ikke hadde bidratt til å sikre bevis, i form av en promilletest, i en situasjon hvor det var nærliggende å tro at han hadde kjørt med promille. ${ }^{36}$ Dette har også blitt lagt til grunn i teorien, ${ }^{37}$ men etter min vurdering lar synspunktet seg vanskelig forsvare. At en person ikke har sikret et bevis, kan tale mot ham i bevisvurderingen - i den grad det tyder på at vedkommende er redd for hva beviset vil avsløre - men om det også leder til en justering av beviskravet, vil det telle mot ham dobbelt opp. Det vil også medføre at vedkommende blir bedømt etter en annen regel enn andre rettssubjekter, og det vil, etter mitt syn, være i strid med prinsippet om likhet for loven, jf. blant annet Grunnloven $§ 98$, som her bør veie tyngre enn Høyesteretts uttalelser. ${ }^{38}$

\section{Den rettslige bevisbyrden}

Så langt har vi sett hvordan det som skal bevises i en konkret sak - et rettslig bevistema - er avledet av rettsreglenes rettsvilkår, og at denne hypotesen må oppfylle beviskravet for at bestemmelsens rettsvirkning skal inntre. Med disse to brikkene trygt plassert kan vi gå videre til å se på hvor bevisbyrden hører hjemme i puslespillet.

Ordet «bevisbyrde» brukes i forskjellige betydninger og relasjoner i juridisk teori og praksis, og det er avgjørende at vi ikke blander disse sammen. Den på mange måter viktigste formen for bevisbyrde $\mathrm{i}$ jussen, som har gitt navn til denne artikkelen, er det jeg kaller den rettslige bevisbyrden, som er risikoen for at et rettslig bevistema ikke er godtgjort på en måte som tilfredsstiller beviskravet. Kort sagt er den rettslige bevisbyrden risikoen for at beviskravet ikke er oppfylt. ${ }^{39}$ Med uttrykket «rettslig bevisbyrde» peker vi ut den av partene som en avgjørelse skal gå imot om beviskravet ikke er oppfylt. En enkel metode for å identifisere denne parten er uvitenhetstesten: Vi forestiller oss en situasjon hvor vi er helt uvitende - og hvor vi derfor ikke har noen holdepunkter for at bevistemaet er sant - og spør hvem avgjørelsen skal gå imot om vi på dette tidspunktet måtte fatte en beslutning.

Det er ikke vanskelig å se hvem som har den rettslige bevisbyrden i våre eksempler. Påtalemyndigheten påberoper seg et rettslig bevistema om at Peder Ås har drept Lars Holm. Den har risikoen for at dette ikke er bevist utover enhver rimelig tvil; er det ikke det, skal påtalemyndigheten ikke få medhold. Marte, på sin side, påberoper seg et rettslig bevistema om at smartklokken har en mangel som ikke skyldes forhold på hennes side. Hun har risikoen for at dette ikke er bevist med sannsynlighetsovervekt; er det ikke det, skal hun ikke få medhold.

Det er heller ikke vanskelig å se hvilket mønster disse to eksemplene inngår i. Påberoper man seg et rettslig bevistema, har man risikoen for at dette ikke oppfyller beviskravet. Det man sier når man påberoper seg et rettslig bevistema, er jo simpelthen at rettsvilkåret for en rettsfølge er oppfylt i et konkret tilfelle, og da bærer man naturlig nok risikoen for at dette ikke blir godtgjort på en måte som tilfredsstiller beviskravet; er beviskravet ikke oppfylt, skal man ikke få medhold. Dette gjør at vi kan si helt generelt: Den rettslige bevisbyrden hviler alltid på den som påberoper seg et rettslig bevistema. Eller: Den rettslige bevisbyrden hviler alltid på den part som påberoper seg at rettsvilkåret (i en rettsregel som knytter rettslige følger til faktuelle vilkår) er oppfylt.

\footnotetext{
${ }^{36}$ Se Rt. 1990 s. 688, på s. 690-691.

${ }^{37}$ Se nærmere Hov (2010) s. 1157-1159; Robberstad (2018) s. 303; Skoghøy (2017) s. 936-937.

${ }^{38}$ Se nærmere Jerk $\varnothing$ (2017) s. 355-371.

${ }^{39}$ Den rettslige bevisbyrden angår altså ikke tilfeller hvor det er tvil om beviskravet er oppfylt, slik det noen ganger hevdes. Regler om en slik tvilsrisiko har lite for seg, se Jerkø (2017) s. 219-226.
} 
I en sak hvor det er flere rettslige bevistemaer, kan vi skille mellom de deler av saken hver av partene har den rettslige bevisbyrden for, gjennom å identifisere hvilke rettslige bevistemaer de har påberopt seg.

Dersom Lillevik elektro påberoper seg at Marte har reklamert for sent, har butikken den rettslige bevisbyrden for dette. Det er lett å bekrefte dette med uvitenhetstesten: Vi forutsetter at vi er i en situasjon hvor vi er helt uvitende, og hvor vi altså ikke har noen holdepunkter for at Marte $i k k e$ har reklamert innen rimelig tid. Det er klart at uten holdepunkter for dette kan retten ikke legge det til grunn, og den kan dermed heller ikke legge til grunn rettsfølgen: at Marte har tapt sin rett til å gjøre mangelen gjeldende. Så avgjørelsen av dette spørsmålet skal gå imot butikken med mindre det er bevist med

sannsynlighetsovervekt. Om det i stedet gjaldt et generelt vilkår om rettidig reklamasjon for å kreve retting, ville dette ikke vært et selvstendig rettslig bevistema; da ville løsningen blitt den motsatte. ${ }^{40}$

Hvis partene i et avtaleforhold er uenige om hvordan honoraret skal fastsettes, og de påberoper seg to forskjellige konkretiseringer av vilkårene for en avtaleinngåelse, vil de ha den rettslige bevisbyrden for hvert sitt rettslig bevistema. Hvis part A hevder at det er avtalt en fast pris, mens B hevder at det er avtalt gjengs pris, har hver av partene som et utgangspunkt ${ }^{41}$ den rettslige bevisbyrden for hvert sitt rettslig bevistema. A skal få medhold om det er sannsynlighetsovervekt for at det er avtalt fast pris; B skal få medhold om det er sannsynlighetsovervekt for at det er avtalt gjengs pris. I et slikt eksempel må vi imidlertid også være oppmerksomme på et tredje alternativ: Det kan være at det ikke er sannsynlighetsovervekt for noen av disse alternativene, fordi det også er en mulighet at ingenting tilstrekkelig konkret har blitt avtalt mellom partene. I så fall må avtalen utfylles gjennom en tolkning av bakgrunnsretten med videre, og da er vi utenfor den rettslige bevisbyrdens domene. Den rettslige bevisbyrden (og beviskravet) gjelder kun faktiske forutsetninger - som er det man kan føre bevis for - i dette tilfellet de faktiske forutsetninger for at noe er avtalt.

Tilsvarende: Om Knoll og Tott bringer sin disputt inn for retten, har de den rettslige bevisbyrden for sine respektive rettslige bevistemaer. Slik dette eksempelet ble presentert over, har vi ingen holdepunkter for hva som mer konkret har funnet sted mellom partene, så dette må gjøres til gjenstand for konkret bevisførsel. Hvis den antatte avtalen ble inngått en fuktig kveld på en støyende bar, hvor Knoll gjentatte ganger sa «hatt», mens Tott sa «katt», vil det være rimelig å konkludere med at de bare har snakket forbi hverandre, og at de begge tar feil når de legger til grunn at de har inngått en avtale. Om det derimot er klare holdepunkter for at avtalen gjelder en katt - Tott tok kontakt med Knoll etter at sistnevnte hadde avertert sin katt for salg på Finn.no - kan det være at retten må gi Tott medhold; det kan tenkes at Knoll angrer og tror han kan lure seg unna basert på den uriktige forestilling at det er umulig å bevise hva som er mest sannsynlig i et muntlig avtaleforhold - når «ord står mot ord». Har retten ingen holdepunkter for hva som er mest sannsynlig, vil det ikke være sannsynlighetsovervekt for noen av delene, og da bør heller ingen av partene få medhold. ${ }^{42}$

På tross av at man ofte kan støte på betegnelsen «bevisbyrderegel», samt andre utsagn som kan gi inntrykk av at bevisbyrden er styrt av egne regler, er det følgende en helt vesentlig innsikt: Det finnes ingen rettsregler - ingen såkalte bevisbyrderegler - om den rettslige bevisbyrden. Påtalemyndigheten har ikke den rettslige bevisbyrden når den tar ut tiltale mot Peder Ås, på grunn av en rettsregel som slår fast at bevisbyrden hviler på påtalemyndigheten i et slikt tilfelle. Vi kunne riktignok ha formulert en regel som konstaterte dette, men denne hadde vært fullstendig overflødig. Når påtalemyndigheten tar ut tiltale mot

${ }^{40}$ Dette innebærer at vi må skille mellom vilkår som tilhører samme regel og vilkår som hører til forskjellige regler. Om slik individuering av rettsregler, se Jerk $\varnothing$ (2017) s. 134-154.

${ }^{41}$ Dette utgangspunktet kan i enkelte avtaleforhold modifiseres av rettsregler som f.eks. § 32 (3) i lov 16. juni 1989 nr. 63 om håndverkertjenester m.m. for forbrukere, som slår fast at det ved uenighet er opp til tjenesteyteren å godtgjøre om en prisangivelse er en bindende fast pris, en høyeste pris, et prisoverslag eller bare en uforpliktende prisantydning. Dette er et eksempel på en (implisitt) legalpresumsjon, som vi skal se nærmere på i punkt 5.3 under.

${ }^{42}$ Det siste har av enkelte blitt oppfattet som kontroversielt, men det er vanskelig å forsvare en alternativ løsning på en slik problemstilling, eller i det hele tatt å se hva denne burde gå ut på. Se i denne forbindelse drøftelsen av gin-eksempelet i Jerk $\varnothing$ (2017) s. 214-219. 
Peder Ås, får den den rettslige bevisbyrden simpelthen som en konsekvens av at den baserer sin påstand om straff på en rettsregel som krever bevis utover enhver rimelig tvil. Tilsvarende får Marte den rettslige bevisbyrden som en konsekvens av at hun påberoper seg en rettsregel som er tilknyttet et krav om sannsynlighetsovervekt, ikke på grunn av en selvstendig rettsregel. Og dette lar seg også generalisere: At den rettslige bevisbyrden alltid hviler på den som påberoper seg et rettslig bevistema, gjelder som en nødvendig regularitet; det er ikke en selvstendig rettsregel. Den rettslige bevisbyrden - risikoen for at beviskravet ikke er oppfylt - er simpelthen en konsekvens av påberopte rettsregler og beviskrav.

Implikasjonen av dette er at vi faktisk kunne klart oss helt uten ordet «bevisbyrde». Bevisbyrden er ikke en nødvendig brikke i en teori om bevisvurderingens rettslige rammer. Enhver rettslig påstand må ha et grunnlag i rettsregler som angir et rettsvilkår og en rettsfølge. Rettsfølgen skal i det konkrete tilfellet inntre hvis og bare hvis det rettslige bevistemaet er godtgjort på en måte som tilfredsstiller beviskravet. Alt en dommer egentlig trenger en forståelse av, er derfor beviskravet og de hovedsakelig materielle ${ }^{43}$ rettsreglene som kan begrunne partenes rettslige påstander (samt legalpresumsjoner, som vi skal se nærmere på i punkt 5.3), og så må hun for hvert rettsvilkår vurdere om det er tilstrekkelig godtgjort eller ikke, og fatte en beslutning i overensstemmelse med dette. (For partene, og for deres erfaring av hva som foregår i en rettssak, kan ordet derimot hevdes å spille en viktig rolle, ved at det peker ut den som har risikoen for at beviskravet ikke er oppfylt. Det er dessuten et så sentralt ord i juristers ordforråd at det neppe er realistisk å kvitte seg med det. $)^{44}$

Mot denne bakgrunn kan det virke underlig at bevisbyrden har vært så omstridt, og at begrepet har vært forbundet med så mye uklarhet. Årsakene til dette er sammensatte og stikker dypt, og jeg vil ikke forfølge disse her, men på overflaten manifesterer de seg i oppfatninger om at bevisbyrden i mange situasjoner er såkalt delt eller omvendt. Slike eksempler har blitt tatt til inntekt for at det er umulig å si noe generelt om bevisbyrden, fordi det til enhver tenkelig generalisering vil finnes en rekke konkrete unntak.

Men den rettslige bevisbyrden for et rettslig bevistema er selvsagt aldri delt eller omvendt. En delt rettslig bevisbyrde ville måtte innebære at partene delte risikoen for at beviskravet ikke er oppfylt. Det kunne gitt mening om rettssaken var et slags samarbeidsprosjekt, men det er den jo ikke. Og en omvendt rettslig bevisbyrde ville måtte innebære at en part hadde risikoen for hva motparten ikke klarte å bevise, for eksempel slik at Peder Ås hadde risikoen for at påtalemyndigheten ikke klarte å bevise utover enhver rimelig tvil at Ås hadde drept Lars Holm. Det kunne kanskje gitt mening i bakvendtland, men det gir liten mening i den virkelige verden.

Så hva er det egentlig som foregår i slike eksempler, hvor oppfatningen er at bevisbyrden er delt eller omvendt? Siden det gir liten mening å si dette om den rettslige bevisbyrden, er det nærliggende å mistenke at oppfatningen - om den skal gi noen som helst mening - må bero på en sammenblanding av en rettslig bevisbyrde med noe annet. Som vi skal se eksempler på, er dette også tilfellet.

Et klassisk eksempel på én form for sammenblanding ser vi i teoriens drøftelse av spørsmålet om hvem som har bevisbyrden når en person som hevder at han har et krav basert på en avtale, blir møtt med den innsigelse at kravet allerede er innfridd. Det er en vanlig oppfatning i teorien at saksøker da vil ha bevisbyrden for at kravet har oppstått, mens saksøkte har bevisbyrden for at kravet er innfridd. ${ }^{45}$ Begge parter har altså hver sin bevisbyrde, og det har ført til at bevisbyrden i eksempler som dette karakteriseres som «delt». For eksempel lar Ekelöf med flere dette eksempelet introdusere begrepet om delt bevisbyrde:

«Båda parter kan som regel inte bära bevisbördan för ett och samma rättsfaktum. Däremot kan en part vara bevisskyldig för ett rättsfaktum och andra parten för ett annat rättsfaktum. Man säger då att bevisbördan är delad. Som exempel kan nämnas att den som anser sig betalningsberättigad skall styrka

\footnotetext{
${ }^{43}$ Et unntak til dette, hvor prosessuelle regler spiller inn, gjelder ved krav på fastsettelsesdom, se Jerk $\emptyset$ (2017) s. 132-134.

${ }^{44}$ Se nærmere Jerk $\varnothing$ (2017) s. 202-204.

${ }^{45}$ Se f.eks. O. Augdahl, Om bevisbyrden i tvistemål, Oslo 1929, s. 22; Skoghøy (2017) s. 917.
} 
sitt påstående om att han lämnat ett lån til gäldenären, men att denne skall bevisa att han erlagt betalning til borgenären.» ${ }^{46}$

Etter mitt syn gir det i beste fall en svak beskrivelse av gjeldende rett å si at bevisbyrden er «delt» i et tilfelle som dette. Den ene parten bygger sitt krav på vilkårene for en avtaleinngåelse, og har som en konsekvens den rettslige bevisbyrden for at avtalen har blitt inngått. Den andre parten bygger sin innsigelse på vilkår for forpliktelsens opphør, og har som en konsekvens den rettslige bevisbyrden for at kravet er innfridd. Partene har altså hver sin rettslige bevisbyrde for hvert sitt rettslig bevistema; det er ikke én bevisbyrde som er delt mellom partene. Slik sett er betegnelsen misvisende. Det som er mer problematisk, er at ordbruken indikerer at det her gjelder et mer eller mindre vilkårlig unntak fra det som ellers skulle være det normale. Og det er slettes ikke tilfellet. Slik sett er dette en ordbruk som står i veien for en god forståelse av jussen, og som gjør at den fremstår mer komplisert enn den egentlig er.

I eksempelet over ble altså to rettslige bevisbyrder blandet sammen. I andre tilfeller blandes en rettslig bevisbyrde sammen med andre former for bevisbyrde. Det skal vi se eksempler på i de neste to punktene, om bevisføringsbyrden og argumentativ bevisbyrde.

\section{Bevisføringsbyrden}

\subsection{Bevisføringsbyrden og evidens}

Så langt har vi sett hvordan ordet «bevisbyrde» kan brukes til å peke ut den av partene som en avgjørelse skal gå imot om beviskravet ikke er oppfylt, eller som har risikoen for at beviskravet ikke er oppfylt. Jeg kaller dette den rettslige bevisbyrden. I en annen, men beslektet betydning brukes ordet «bevisbyrde» også naturlig om den som, i en forstand, må føre bevis for det rettslige bevistemaet. En slik bevisføringsbyrde har i teorien blitt kalt «subjektiv» (i kontrast til «objektiv»), «falsk» (i kontrast til «ekte») eller «kontekstuell» bevisbyrde (i kontrast til den rettslige bevisbyrden). Her kan vi holde oss til uttrykket «bevisføringsbyrde».

Så hvem er det som må føre bevisene? Når straffesaken mot Peder Ås starter, før noen bevis har blitt ført, har retten ingen holdepunkter for at Ås er skyldig; da er beviskravet ikke oppfylt. Det medfører at påtalemyndigheten, i denne konteksten, er nødt til å føre bevis om den ønsker at Ås skal bli funnet skyldig. Antar vi at påtalemyndigheten legger frem tekniske bevis for at Ås sine fingeravtrykk er på $\varnothing \mathrm{ksen}, \mathrm{og}$ at $\emptyset \mathrm{ksen}$ er drapsvåpenet, kan det være at retten vil føle seg overbevist om at Ås har drept Holm. Foreligger det ikke lenger rimelig tvil, vil det nå, i denne nye konteksten, være opp til Ås å føre bevis for at han er uskyldig. Hvis retten så blir presentert for dødstidspunktet og overvåkningsbildene fra Oslo S som sår tvil om Ås var i Holms leilighet på gjerningstidspunktet, vil det på ny kunne foreligge rimelig tvil. I denne konteksten vil igjen påtalemyndigheten ha en bevisføringsbyrde.

Det som her veksler mellom partene, ettersom beviskravet anses oppfylt eller ikke, er utelukkende bevisføringsbyrden. Den rettslige bevisbyrden - risikoen for at beviskravet ikke er oppfylt - vil aldri veksle mellom partene; denne ligger fast helt uavhengig av hvordan bevissituasjonen måtte være i øyeblikket. Derfor kan det være misvisende å si at bevisbyrden i slike tilfeller er «omvendt», eller at den «snus», slik det noen ganger hevdes. Selv om den noen ganger omtales som det, er bevisføringsbyrden heller ingen bevisføringsplikt. ${ }^{47}$ Enn videre er det heller ikke slik at partene faktisk bytter på å føre bevis ettersom beviskravet er oppfylt eller ikke. Det er bare slik at dommeren vil kunne veksle mellom å tenke «nå er jeg overbevist» og «nå er jeg i tvil» ettersom saken skrider frem. Den bevisføringsbyrden peker ut, er simpelthen den som i øyeblikket har en bedre grunn enn motparten til å føre bevis.

I jussen brukes ordet «bevis» gjerne om en saks bevismidler, slik som tekniske bevis og vitnebevis. Retten kan imidlertid også (i en viss utstrekning, som er bestemt av prosessreglene) bygge på forhold som

\footnotetext{
${ }^{46}$ Per Olof Ekelöf, Henrik Edelstam, og Lars Heuman, Rättegång IV, 7. utgave, Stockholm 2009, s. 81.

${ }^{47}$ Se f.eks. Rt. 1998 s. 774 Videospillerdommen, på s. 779.
} 
er erkjent av partene, samt andre kjensgjerninger som ikke er omstridte. Slike faktiske holdepunkter kan også ha innflytelse på om beviskravet er oppfylt. En fellesbetegnelse på bevis og andre faktiske holdepunkter som kan ha bevisverdi i en sak, er «evidens». Evidens er noe vi kan si peker utover seg selv, ${ }^{48}$ slik for eksempel en vitneobservasjon eller et fingeravtrykk kan peke mot at Peder Ås drepte Lars Holm, eller slik en ødelagt smartklokke kan peke mot at den har en mangel. Uttrykt på en annen måte kan vi si at noe utgjør evidens for (eller mot) en hypotese om det påvirker hypotesens sannsynlighet, altså om vi etter å ha blitt forelagt evidensen vil endre vår vurdering av hypotesens sannsynlighet.

På tilsvarende vis som i en straffesak vil bevisføringsbyrden i sivile saker veksle mellom partene ettersom et beviskrav anses oppfylt eller ikke. Ved sakens begynnelse vil saksøker normalt ha bevisføringsbyrden for sine rettslige bevistemaer. Men dette gjelder ikke uten unntak. Her kan det tenkes at det finnes faktiske holdepunkter som allerede er erkjent av partene og som i egenskap av evidens for det rettslige bevistemaet er tilstrekkelig til å innfri beviskravet. Det kan altså være at vi ved forhandlingenes begynnelse allerede befinner oss i en kontekst hvor bevisføringsbyrden har gått over på den annen part. I tillegg kan det selvsagt også tenkes at partene er enige om hva faktum er, og at det kun er jussen som er omstridt i saken (i hvilket fall det er mindre naturlig å snakke om bevisbyrden). ${ }^{49}$

\subsection{Bevisføringsbyrden og faktiske presumsjoner}

- Doctor Livingstone, I presume? Henry Morton Stanleys ord da han i 1871 støtte på David Livingstone ved Tanganyika-sjøen i det nåværende Tanzania, har blitt berømte. Så vidt Stanley visste, fantes det ingen andre hvite i mils omkrets. Synet av en hvit mann gjorde det derfor rimelig for ham å anta - å presumere - at dette måtte være den berømte legen han hadde reist til Afrika for å finne.

I jussen går slike rimelige antagelser gjerne under betegnelsene «(faktisk) presumsjon» eller «(faktisk) formodning». For eksempel kan en persons ustøe gange og snøvlete tale utløse en presumsjon om at personen er påvirket av alkohol. Dette gjelder ikke ubetinget; det er ikke alltid rimelig å anta at ust $\varnothing$ gange og snøvlete tale er et tegn på alkoholpåvirkning. På en teaterscene eller på et sykehus kan det være naturlig å presumere annerledes. Faktiske presumsjoner kan også undertrykkes av konkrete opplysninger, for eksempel om at personen har en medisinsk lidelse eller akkurat har fått fjernet en visdomstann.

Formodninger kan gi grunnlag for en prima facie («ved første øyensyn») oppfatning om at noe er tilfellet. Denne oppfatningen kan så bli styrket eller svekket når det kommer til ytterligere informasjon.

Hvis en person krever erstattet fremtidig arbeidsinntekt etter en ulykke som har gjort ham arbeidsufør, vil det gjerne være naturlig å presumere at den tapte, fremtidige inntekten ville ha korrespondert med lønnen vedkommende har hatt i tiden forut for ulykken (justert i samsvar med lønnsutviklingen). Dette gjelder ikke ubetinget. For eksempel er det en lite rimelig antagelse om personen studerer og så langt bare har hatt noen småjobber på si. Og hvis vi blir klar over at en skadelidt i full jobb hadde gode utsikter til en forfremmelse, kan det også være vi vil vurdere saken annerledes. Men uten konkrete holdepunkter for noe annet er det naturlig å bygge på presumsjonen. Det har formodningen mot seg at noen uten videre ville fått en $100 \%$ lønnsøkning.

Bygger man sitt krav på en påstand som i utgangspunktet er lite sannsynlig - som har presumsjonen mot seg - vil det kreves sterkere bevis for å innfri beviskravet. Det er altså ingen statisk sammenheng mellom beviskravet og hvilke bevis som kreves, og det forekommer at uttalelser om hvilke bevis som kreves, forveksles med uttalelser om beviskravet. Dette er en sammenblanding man bør være på vakt mot.

I Rt. 2003 s. 338 Dykkerdommen anførte skadelidte, som i de forutgående år hadde hatt en gjennomsnittlig årsinntekt på 500000 kroner, at han i de påfølgende år ville ha tjent oppimot 1,3 millioner kroner. Til dette uttalte Høyesterett:

\footnotetext{
${ }^{48}$ Ian Hacking, The Emergence of Probability: A Philosophical Study of Early Ideas about Probability, Induction and Statistical Inference, 2. utgave, Cambridge 2006, s. 34.

${ }^{49}$ Se også Jerk $\emptyset$ (2017) s. 155-157.
} 
«A har tvilsrisikoen [bevisbyrden] for tapets størrelse, og når det anføres at det ville ha skjedd en så betydelig økning som i dette tilfellet, skjerpes kravet til hvilke bevis som må fremlegges for at det påståtte tapet skal være sannsynliggjort.» ${ }^{50}$

Uttalelsen om at kravet til bevis «skjerpes», er tvetydig. Den kan tolkes slik at beviskravet skjerpes - slik har faktisk Høyesterett selv tolket uttalelsen i Rt. 2010 s. 584 (avsnitt 61) - men det harmonerer dårlig med resten av setningen, som sier at «tapet skal være sannsynliggjort». Det hadde også medført at personen ble bedømt etter et strengere beviskrav enn andre som krevde erstatning, så det er neppe en holdbar tolkning. Bedre mening gir det å si at fordi et så stort lønnshopp klart har formodningen mot seg - det er i utgangspunktet lite sannsynlig - må det desto sterkere bevis til for at denne hypotesen skal oppfylle det ordinære beviskravet. ${ }^{51}$

Ved beregningen av tapets størrelse vil det normalt også være naturlig å presumere at skadelidte, om ulykken ikke hadde skjedd, ville ha stått i lønnet arbeid frem til pensjonsalder. Helt sikkert er dette selvsagt ikke. Han kunne blitt rammet av et hjerneslag, fått en takstein i hodet eller blitt truffet av lyn fra klar himmel bare dager, måneder eller noen få år senere, slik at tapet uansett ville ha oppstått av en annen årsak (med redusert erstatning som konsekvens). Det er allikevel klart at skadelidte normalt ikke trenger å føre bevis for at slike alternative, hypotetiske hendelser ikke ville ha inntruffet. Dette kan begrunnes med en faktisk presumsjon: Slike alternative skadeårsaker har i utgangspunktet en sterk formodning mot seg de er i utgangspunktet så usannsynlige - at vi normalt kan se helt bort fra disse.

Fordi faktiske presumsjoner kan ha innflytelse på hva partene må føre bevis for, hender det også at faktiske presumsjoner tas til inntekt for at bevisbyrden er snudd eller omvendt. Dette er en annen sammenblanding vi bør være på vakt mot.

Rt. 2001 s. 320 Psykoinvaliditetdommen gjaldt en persons krav på erstatning, blant annet for tap av fremtidig inntekt, etter at han hadde vært utsatt for en trafikkulykke. Hans påfølgende invaliditet hadde blitt utløst av ulykken, men var i stor grad av psykosomatisk art, og forsikringsselskapet anførte derfor at han med stor sannsynlighet ville ha blitt invalid etter hvert, også om han ikke hadde blitt utsatt for trafikkulykken. Etter å ha konstatert at skadelidte i utgangspunktet har bevisbyrden, uttalte retten at

«Dersom det fra den som ansvar blir rettet mot, blir hevdet at hvis ulykken ikke hadde inntruffet, ville skade ha inntrådt av en annen årsak, må imidlertid tvilsrisikoen [bevisbyrden] for den alternative skadeutvikling gå over på denne, såfremt den alternative skadeårsak ikke har noe med den aktuelle ulykke å gjøre $\ldots\rangle^{52}$

Her hevdes det altså at bevisbyrden «går over på» den som ansvar blir rettet mot, dersom denne påberoper seg en uavhengig, alternativ skadeårsak. I teorien har dette også blitt utlagt slik at Høyesterett har «gjort unntak» fra en angivelig hovedregel om at skadelidte har bevisbyrden, ved at bevisbyrden «snus». ${ }^{53}$ Ingen av delene er helt dekkende.

Skadelidte har den rettslige bevisbyrden for at de generelle vilkårene for erstatning er oppfylt, og vil dermed alltid ha risikoen for at retten på grunn av en mulig hypotetisk skadeårsak ikke anser beviskravet oppfylt. Det gjelder derfor ikke noe unntak fra utgangspunktet i tilfeller som dette. Dersom det videre er klart at erstatningsvilkårene for øvrig er oppfylt, slik at erstatningen står og faller på en mulig alternativ skadeårsak, blir det avgjørende om det er sannsynlighetsovervekt for denne. Det vil det i utgangspunktet ikke være, fordi slike har en klar presumsjon mot seg. Og det innebærer at i en slik situasjon, hvor det er godtgjort at erstatningsvilkårene for øvrig er oppfylt og presumsjonen mot alternative skadeårsaker ikke er tilbakevist, vil beviskravet være oppfylt. Skadelidte har da oppfylt sin bevisføringsbyrde, med den konsekvens at bevisføringsbyrden nå har gått over på den som ansvar blir gjort gjeldende mot. I denne

\footnotetext{
${ }^{50}$ Rt. 2003 s. 338 Dykkerdommen, avsnitt 67.

${ }^{51}$ For flere slike sammenblandinger, se Jerk $\varnothing$ (2017) s. 344-355.

${ }^{52}$ Rt. 2001 s. 320 Psykoinvaliditetdommen, på s. 329 med videre henvisninger til rettspraksis.

${ }^{53}$ Skoghøy (2017) s. 921-922.
} 
konteksten er det opp til han å føre bevis mot det rettslige bevistemaet, og en måte han kan gjøre dette på er å føre bevis for at en alternativ skadeårsak ville ha inntruffet. Men en forutsetning for dette er altså at erstatningsvilkårene for øvrig anses oppfylt - bevisføringsbyrden for det rettslige bevistemaet vil ikke gå over på den annen part bare fordi man «hevder» at skaden ville inntrådt av en annen årsak. Søkte påstander alene forandrer ingenting. ${ }^{54}$

\subsection{Bevisføringsbyrden og legalpresumsjoner}

En legalpresumsjon (alternativt: «legal presumsjon» eller «lovsformodning») er en rettslig regulert presumsjon. Et eksempel er likestillings- og diskrimineringsloven ${ }^{55} \S 37$. Første ledd slår fast:

«Diskriminering skal anses å ha skjedd hvis det foreligger omstendigheter som gir grunn til å tro at diskriminering har skjedd, og den ansvarlige ikke sannsynliggjør at diskriminering likevel ikke har skjedd.»

Om for eksempel en arbeidstaker krever erstatning fra sin arbeidsgiver på grunn av ulovlig diskriminering, jf. lovens $\S 38$, er utgangspunktet at arbeidstakeren må bevise med sannsynlighetsovervekt at vilkårene for erstatningskravet er oppfylt, herunder at han har blitt utsatt for ulovlig diskriminering. Legalpresumsjonen modifiserer dette utgangspunktet. Den medfører at arbeidstakeren ikke trenger å godtgjøre at det har funnet sted diskriminering; det er tilstrekkelig om han fører bevis for de «omstendigheter som gir grunn til å tro at diskriminering har skjedd». Dersom han fører adekvate bevis for dette, skal det legges til grunn - da skal det formodes - at diskriminering har funnet sted; dette gjelder så lenge arbeidsgiveren ikke «sannsynliggjør at diskriminering likevel ikke har skjedd».

I likhet med faktiske presumsjoner har legalpresumsjoner betydning for hva partene må føre bevis for. Det er derfor ikke uvanlig at legalpresumsjoner omtales som bevisbyrderegler ${ }^{56}$ eller tas til inntekt for at bevisbyrden er delt eller omvendt. Dette gjelder også likestillings- og diskrimineringsloven $§ 37$. Den har «Bevisbyrde» som overskrift, i forarbeidene omtales bestemmelsen som en regel om delt bevisbyrde,$^{57}$ og det er også vanlig i teorien å omtale bestemmelsen som en regel om delt eller omvendt bevisbyrde, ikke som en legalpresumsjon.$^{58}$ Hvilken betegnelse man bruker som en merkelapp på bestemmelser som denne, er i seg selv av liten betydning. Men det er klart at bestemmelsen er en legalpresumsjon, og betegnelsene «delt» og «omvendt» bevisbyrde er i beste fall lite informative; i verste fall gir de et misvisende bilde av slike bestemmelser og deres rolle i rettsanvendelsen.

En legalpresumsjon alene har ingen rettslig betydning. Den får kun sin betydning i kraft av at den knytter an til rettsvilkåret i en regel som også angir en rettsfølge, slik som regelen om erstatning ved diskriminering. Mens arbeidstakeren i utgangspunktet måtte godtgjøre at samtlige vilkår for erstatning er oppfylt, medfører legalpresumsjonen at beviskravet lettere vil anses oppfylt, fordi det vil presumeres at diskriminering har skjedd, så fremt det foreligger omstendigheter som gir grunn til å tro dette. I en slik kontekst vil altså bevisføringsbyrden gå over på den annen part, som om det ordinare beviskravet var oppfylt. Men en forutsetning for dette er at også de øvrige vilkår for erstatning anses oppfylt.

Bevisføringsbyrden vil for eksempel ikke gå over på arbeidsgiver om det ikke er godtgjort at arbeidstaker

${ }^{54}$ Se nærmere om bevisbyrden og faktiske presumsjoner i Jerkø (2017) s. 157-168.

${ }^{55}$ Lov 16. juni $2017 \mathrm{nr}$. 51 om likestilling og forbud mot diskriminering.

${ }^{56}$ Se f.eks. Rt. 2014 s. 402 (avsnitt 63) om den tilsvarende $§ 16$ i likestillingsloven 1978.

${ }^{57}$ Prop. 81 L (2016-2017) punkt 28.4.

${ }^{58} \mathrm{Se}$, om tilsvarende bestemmelser i tidligere lovgivning, Mary-Ann Hedlund, «Bevisbyrde», i Anne Hellum og Kirsten Ketscher (red.), Diskriminerings- og likestillingsrett, Oslo 2008, s. 323-339; Anne Robberstad, «Om forståelser av bevisbyrde», Jussens Venner, 2011, s. 65-86, på s. 82-83; Aslak Syse og Geir Helgeland, «Reglene om 'delt bevisbyrde' i norsk diskrimineringsrett», i Helga Aune mfl. (red.), Arbeid og rett: festskrift til Henning Jakhellns 70-årsdag, Oslo 2009, s. 585-604. 
har lidd et $\varnothing$ konomisk tap. Den bevisføringsbyrden arbeidsgiver får, gjelder altså ikke ubetinget - eller ved siden av arbeidstakers bevisbyrde, slik uttrykket «delt bevisbyrde kan gi inntrykk av - men den vil på grunn av legalpresumsjonen lettere kunne gå over på arbeidsgiver. Får arbeidsgiver bevisføringsbyrden, kan han slippe unna gjennom å avbevise presumsjonen, men han kan også oppfylle sin bevisføringsbyrde gjennom å argumentere for at de øvrige vilkårene for erstatning allikevel ikke er tilstrekkelig sannsynliggjort.

Bestemmelsen illustrerer hvordan en legalpresumsjon alltid vil bestå av tre ledd. Det første leddet, vilkårsleddet, angir betingelsen for at presumsjonen skal inntre: i dette tilfellet at det foreligger omstendigheter som gir grunn til å tro at diskriminering har skjedd. Det andre leddet, presumsjonsleddet, angir hva presumsjonen går ut på: i dette tilfellet at diskriminering skal anses å ha skjedd. Mens det tredje leddet, avbevisningsvilkåret, angir betingelsen for presumsjonens opphør: i dette tilfellet at den ansvarlige sannsynliggjør at diskriminering likevel ikke har skjedd.

I dette eksempelet er alle de tre leddene eksplisitt angitt (men deres nærmere innhold må fastlegges gjennom en rettslig tolkning). Slik sett er dette et paradigmatisk eksempel på en legalpresumsjon. Andre legalpresumsjoner har en mer tilslørt karakter. For implisitte legalpresumsjoner må man ut fra konteksten og en rettslig tolkning resonnere seg frem til hva ett eller flere av leddene går ut på. Et eksempel på en bestemmelse som lar det meste stå usagt, er viltloven $\S 34$ om retten til å forfølge og tilegne seg storvilt som er såret på lovlig grunn. Første ledd tredje punktum konstaterer simpelthen: «Jegeren har bevisbyrden for lovlig forfølgning. ${ }^{59}$

En legalpresumsjon kan gi uttrykk for en faktisk presumsjon. I så fall vil den få begrenset praktisk betydning. Men det er ikke alle faktiske presumsjoner som gir uttrykk for allmenne oppfatninger; om dommeren selv ville presumert annerledes, kan legalpresumsjonen spille en selvstendig rolle. Hvis en legalpresumsjon slår fast at det under visse omstendigheter skal anses å foreligge diskriminering, så kan ikke dommeren, så fremt disse omstendighetene foreligger, presumere annerledes. Da blir det i så fall opp til den part som må motbevise at det foreligger diskriminering, å godtgjøre dette.

Størst praktisk betydning vil legalpresumsjoner ha der de avviker fra alminnelige faktiske presumsjoner. Hensikten bak slike regler kan være å oppfordre til notoritet, å beskytte parter som har vanskelig for å fremskaffe bevis, eller å sikre en effektiv etterlevelse av reglene der fravær av bevismateriale innbyr til utnyttelse av smutthull i loven. For eksempel vil likestillings- og diskrimineringsloven $\S 37$ kunne bidra til at saker som ellers ikke ville kommet for retten, fordi klageren har vanskelig for å bevise hvilke motiver som har ligget til grunn for den innklagedes beslutninger, allikevel blir prøvd. Den vil også kunne bidra til at arbeidsgivere og andre i større grad betenker seg før de diskriminerer, og at de ikke opptrer på en måte som kan gi grunn til å tro at diskriminering har funnet sted, uten å kunne dokumentere at beslutningene er basert på lovlige motiver.

Forbrukerkjøpsloven $§ 18$ annet ledd slår fast at en mangel som viser seg innen seks måneder etter risikoens overgang, hvis ikke noe annet bevises, skal formodes å ha eksistert ved risikoens overgang. Dette er en legalpresumsjon som i stor grad er uttrykk for en faktisk presumsjon. Om et produkt i løpet av kort tid går i stykker, vil det ofte være nærliggende å formode at det skyldes en mangel. Ved at dette slås eksplisitt fast, klargjøres forbrukerens rettsstilling. Samtidig styrkes den potensielt i saker hvor den legale presumsjonen går ut over den faktiske.

Hvis Marte hadde reklamert senest seks måneder etter kjøpet, kunne hun ha påberopt seg denne legalpresumsjonen. Da ville det vært opp til Lillevik elektro å bevise at en eventuell mangel allikevel ikke forelå på kjøpstidspunktet. Ettersom Marte først reklamerte noe senere, kommer presumsjonen imidlertid ikke til anvendelse. Hva har det å si for Martes rettsstilling?

I Rt. 1998 s. 774 Videospillerdommen er det en interessant anførsel om dette. Et av sakens sentrale spørsmål var om en svikt i IR-mottakeren, som fanger opp signalene fra fjernkontrollen, på en drøyt tre år gammel videospiller kunne føres tilbake til en mangel som forelå på leveringstidspunktet. En teknisk undersøkelse var ansett å være for dyr og tidkrevende. Hva årsaken faktisk var, lå derfor utenfor partenes

${ }^{59} \mathrm{Om}$ implisitte legalpresumsjoner, og om bevisbyrden og legalpresumsjoner mer generelt, se Jerk $\varnothing$ (2017) s. 168-181; se også s. 181-196. 
og rettens kunnskap. Dermed oppstod spørsmålet om hvilken av partene som skulle bære risikoen for denne uklarheten. I kjøpers anførsler ble det hevdet at det måtte gjelde en legalpresumsjon [særlig bevisbyrderegel] til fordel for forbrukeren, og at forbrukere uten en slik presumsjon ville være «hjelpeløse og utsatt for rettsfornektelse». ${ }^{60}$ Det fantes ingen klare holdepunkter for at det gjaldt en slik legalpresumsjon, så den første delen av anførselen ble med rette avvist av Høyesterett. Men innebærer fraværet av en slik legalpresumsjon at forbrukere vil være hjelpeløse og utsatt for rettsfornektelse?

La oss forestille oss at Marte hadde kjøpt en videospiller, fraktet den forsiktig hjem, og plassert den trygt på en hylle under TV-en, hvor den ble stående uten ytre påkjenninger frem til den plutselig etter drøyt tre år sluttet å virke. Har videospilleren en mangel? Svaret er et ubetinget ja. Om den går i stykker, må det enten skyldes en ytre påkjenning eller en svikt ved videospilleren selv. Forutsatt at ytre påkjenninger var fraværende, er det klart at svikten må bero på spilleren selv.

I praksis vil en slik forutsetning naturlig nok sjelden gjøre seg gjeldende. Som et fysisk produkt vil en videospiller nødvendigvis være gjenstand for ytre påkjenninger, selv om de fleste av disse ved normal bruk vil ligge innenfor det en videospiller skal tåle. En dommer kan dessuten ikke vite med sikkerhet hvilke påkjenninger en videospiller har vært utsatt for, og dermed heller ikke om den har en mangel. Så spørsmålet blir hvordan retten bør forholde seg til denne usikkerheten.

Anførselen om at forbrukere uten en legalpresumsjon vil være hjelpeløse og utsatt for rettsfornektelse, synes å bero på en oppfatning om at kjøpere ellers vil være avhengige av en dyr teknisk undersøkelse for å oppfylle sin bevisføringsbyrde. Det har vi ingen grunn til å akseptere. For Marte har her et annet vektig bevis hun kan fremlegge, nemlig den ødelagte videospilleren, som under normale omstendigheter i seg selv vil kunne være tilstrekkelig til å oppfylle beviskravet. Når en teknisk komponent med lang levetid som befinner seg inne i en boks av metall eller hard plast, og som under normale omstendigheter står fast plassert innendørs, har blitt $\varnothing$ delagt og boksen ikke viser noen indikasjoner på at den har blitt mistet i bakken, tuklet med eller skadet på annen måte, så kan det skape en (faktisk) presumsjon for at svikten skyldes en mangel som forelå på leveringstidspunktet. I så fall vil bevisføringsbyrden gå over på selger, og da vil det være opp til denne å foreta en eventuell teknisk undersøkelse for å tilbakevise presumsjonen.

En smartklokke er et annerledes produkt, som ved aktiv bruk vil være gjenstand for helt andre og antagelig sterkere fysiske påkjenninger enn en videospiller. Men det er ikke dermed sagt at Marte har en tapt sak. Løsningen på saken beror som nevnt på tolkningen av uttrykket «vannavvisende»; la oss her forutsette at en slik klokke skal kunne brukes til svømming, men ikke til dykking under fem meter. Salgsrepresentanten hos Lillevik elektro hadde anført at Marte ikke kunne bevise at det var noe galt med klokken da hun kjøpte den. Slikt snakk om hva noen kan «bevise», kan være misvisende eller villedende. Det kan gi inntrykk av at det kreves helt sikre bevis. Og Marte kan selvsagt ikke med en slik grad av sikkerhet bevise at det var noe galt med klokken da hun kjøpte den, eller at den ble ødelagt under en svømmetur. Men alt som kreves, er sannsynlighetsovervekt, og spørsmålet blir derfor det følgende: Gitt alt det vi vet om den ødelagte klokken, hva er mest sannsynlig: at den har en mangel, eller at den har gått i stykker på grunn av en ytre påkjenning som forbrukeren må ha risikoen for? Hvis klokken ikke har andre fysiske skader, kan det godt tenkes at det vil være en faktisk presumsjon for at det Marte sier er sant: at klokken ble ødelagt av en svømmetur. I så fall vil bevisføringsbyrden gå over på butikken, som må føre bevis for hvorfor dette ikke er en troverdig konklusjon.

Det er derfor ikke riktig at forbrukere vil være hjelpeløse og utsatt for rettsfornektelse uten en legalpresumsjon. For de vil alltids kunne falle tilbake på en faktisk presumsjon. En sterkere legalpresumsjon til fordel for forbrukere ville medført at de også ville få medhold i situasjoner hvor vi ikke hadde rimelig grunn til å tro at det forelå en mangel. Det er ikke nødvendigvis rimelig. Normalt bør vi derfor kreve klare holdepunkter i loven for å oppstille en legalpresumsjon.

\section{Argumentativ bevisbyrde}

${ }^{60}$ Rt. 1998 s. 774 , på s. 777. 
I saken mot Peder Ås kom mye av bevisførselen til å dreie seg om fingeravtrykkene på øksen. Forsvaret klarte å så tvil både om den generelle bevisverdien til fingeravtrykk og om fingeravtrykkene på øksen var avsatt av Ås. For retten var det uklart hva den kunne legge til grunn. Dermed oppstod spørsmålet: Hvem har den rettslige bevisbyrden for at fingeravtrykkene stammet fra Ås?

Et slikt spørsmål bygger på en misforståelse. Den rettslige bevisbyrden er risikoen for at det rettslige bevistemaet ikke er godtgjort på en måte som tilfredsstiller beviskravet. Og det som skal bevises utover enhver rimelig tvil, er at As har drept Holm; han er ikke tiltalt for å ha plantet fingrene sine på våpenet som drepte ham. Fingeravtrykkene har ingenting med beviskravet å gjøre, og spørsmålet gir derfor ingen mening. Kun forvirring kan bli utfallet av at ordet «bevisbyrde» (eller «beviskrav») knyttes til andre forhold enn det rettslige bevistemaet. Spørsmålet man i stedet bør stille, er om denne usikkerheten, på bakgrunn av bevissituasjonen for øvrig, tilsier at det foreligger rimelig tvil om hvorvidt Ås har drept Holm.

Eksempelet forsvarer allikevel sin plass i en artikkel om bevisvurderingens rettslige rammer fordi det illustrerer hvor nærliggende det kan være å knytte ordet «bevisbyrde» til alle mulige andre forhold som er gjenstand for bevis. Og dette er ikke uvanlig. Det har ikke vært noen tradisjon i norsk rettsvitenskap for å koble analysen av bevisbyrden til en analyse av hva det er som skal bevises; i stedet har ordet «bevisbyrde» vært knyttet til alle mulige forhold som partene argumenterer for. Dette bidrar til å forklare oppfatningen om at bevisbyrden i mange situasjoner er såkalt delt eller omvendt, og at det er umulig å si noe generelt om hvem som har den. ${ }^{61}$ Ett eksempel på en slik utglidning så vi i Rt. 2001 s. 320, hvor bevisbyrden ble knyttet til alternative skadeårsaker. Det er ikke slike forhold skadelidte har den rettslige bevisbyrden for. Det skadelidte må sannsynliggjøre, er at de generelle vilkårene for erstatning er oppfylt, og i de fleste tilfeller kan dette på grunn av en faktisk presumsjon gjøres uten at noen sier et eneste ord om alternative eller hypotetiske skadeårsaker.

Det er allikevel klart at vi $i$ en forstand kan snakke om bevisbyrder også for andre forhold enn et rettslig bevistema. Ordet «bevisbyrde» er et ord i dagligspråket, som helt naturlig kan brukes i en rekke forskjellige situasjoner hvor noen må «bevise» noe eller bærer risikoen for ikke å bli trodd. Men det er viktig at slike $\varnothing$ vrige bevisbyrder ikke blandes sammen med den rettslige. En bevisbyrde for et annet forhold (enn det rettslige bevistemaet) som en part argumenterer for, kaller jeg argumentativ bevisbyrde. ${ }^{62}$

Slik kan vi si at påtalemyndigheten har en argumentativ bevisbyrde for påstanden om at fingeravtrykkene på $\emptyset$ ksen stammer fra Ås. Forklaringen på dette er at dette er et forhold som er egnet til å påvirke vår vurdering av sannsynligheten for at Ås har drept Holm. Retten kan ikke legge det sistnevnte til grunn uten at det er bevist utover enhver rimelig tvil. Den kan derfor heller ikke i sin vurdering legge til grunn at fingeravtrykkene stammer fra Ås, uten at dette er tilstrekkelig underbygget. På den annen side kan retten heller ikke legge til grunn at fingeravtrykkene ikke stammer fra Ås, for dette er et forhold som er egnet til å svekke sannsynligheten for at Ås drepte Holm. Når forsvaret argumenterer for dette, vil den derfor også kunne få en argumentativ bevisbyrde. Uansett hvilket relevant, omstridt forhold det er man argumenterer for, vil man kunne få en argumentativ bevisbyrde for dette forholdet. Dette er imidlertid en bevisbyrde som ikke har noen direkte rettslige implikasjoner. Hvis det oppstår spørsmål om hvem som har (den argumentative) bevisbyrden for et annet forhold enn et rettslig bevistema, er det derfor stort sett et fornuftig råd å se bort fra spørsmålet og heller konsentrere seg om det som faktisk skal bevises.

\section{Bevisvurderingens rettslige rammer oppsummert}

Alle rettslige krav må bygge på rettsregler som angir et rettsvilkår og en rettsfølge. Det som skal bevises et rettslig bevistema - er at rettsvilkåret er oppfylt i et konkret tilfelle. Fordi sikker kunnskap i de fleste situasjoner er uoppnåelig, er jussen i vår moderne tid utstyrt med beviskrav. For hvert rettslig bevistema

\footnotetext{
${ }^{61}$ Jerk $\varnothing(2017)$ s. 220-222.

${ }^{62}$ Se nærmere i Jerk $\varnothing$ (2017) s. 122-125.
} 
må det vurderes om dette tilfredsstiller det tilhørende beviskravet. Påberoper man seg et rettslig bevistema, får man risikoen - den rettslige bevisbyrden - for at beviskravet ikke er oppfylt.

Bevisføringsbyrden vil kunne veksle mellom partene, alt ettersom evidens og faktiske presumsjoner tilsier at beviskravet er oppfylt eller ikke. I noen unntakstilfeller gjelder det også egne legalpresumsjoner som forteller rettsanvenderen hvordan hun skal presumere.

Det kan være uklart hvordan rettsreglene skal tolkes og avgrenses, eller hvor strengt beviskravet er. Det kan også, selv om det bør høre til sjeldenhetene, være uklart om det gjelder en legalpresumsjon på det aktuelle rettsområdet. Og i konkrete bevisvurderinger kan det oppstå uklarhet om hva vi kan slutte fra sakens beviser og annen evidens, hva det er grunn til å presumere, eller hvordan en legalpresumsjon skal forstås, og hvilke implikasjoner den har i det konkrete tilfellet. Alle disse uklarhetene dreier seg om tolkningen og anvendelsen av rettslige normer - (hovedsakelig) materielle rettsregler, beviskrav og legalpresumsjoner - samt om bevisvurdering. Hverken den rettslige bevisbyrden eller bevisføringsbyrden byr i seg selv på noen særegne, interessante utfordringer.

Det som imidlertid kan skape utfordringer, er de oppfatninger om bevisbyrden som hevdes i teori og praksis. Ordet «bevisbyrde» brukes ofte helt udiskriminerende om rettslige bevisbyrder, bevisføringsbyrder og argumentative bevisbyrder. Og sammenblandinger av forskjellige bevisbyrder leder til oppfatninger om at bevisbyrden er delt eller omvendt. - Hvilken form for bevisbyrde siktes det til med ordet «bevisbyrde»? - Hva har blitt blandet sammen når det hevdes at bevisbyrden er delt eller omvendt? Som leser av juridiske tekster hvor bevisbyrden omtales, blir man ofte tvunget til å foreta egne analyser, for å dechiffrere det uuttalte og å reanalysere det sagte. ${ }^{63}$ Med en forståelse av de grunnleggende begreper som er presentert i denne artikkelen, vil man forhåpentlig være rustet også til å foreta slike egne analyser.

${ }^{63}$ For noen eksempler på slike analyser, se Jerkø (2017) s. 181-196 og 204-212. 